\title{
Adopción internacional y competencia judicial internacional en la Ley 54/2007 de 28 de diciembre 2007 de adopción internacional
}

\author{
por \\ Alfonso-Luis Calvo Caravaca \\ Catedrático de Derecho internacional privado \\ Universidad Carlos III de Madrid \\ Vocal Permanente de la Comisión General de Codificación \\ $\mathrm{y}$ \\ Javier Carrascosa González \\ Profesor Titular de Derecho internacional privado \\ Universidad de Murcia
}

Recibido: 10.03 .08

Aceptado: 15.10 .08

Resumen: La regulación de la competencia judicial internacional en relación con la adopción internacional se contiene en los arts. 14 y 15 de la Ley 54/2007 de 28 de diciembre de adopción internacional. Se trata de un abanico de soluciones extraordinariamente creativas. Para la constitución de la adopción se acogen diversos foros: la residencia habitual del adoptando en España, la nacionalidad española del adoptando, la residencia habitual del adoptante en España y la nacionalidad española del adoptante. Estos foros pueden ser reducidos teleológicamente mediante un desarrollo judicial, de modo que se garantice que los tribunales españoles sólo son competentes para constituir adopciones en los casos verdaderamente vinculados con España mediante «conexiones sustanciales» (Minimum Contact Test). Por otro lado, el legislador ha acogido también diversos foros para la modificación, revisión, nulidad y conversión de la adopción simple en adopción plena. Igualmente, se mantiene la posibilidad de que los cónsules españoles acreditados en el extranjero puedan constituir adopciones internacionales.

Palabras clave: adopción internacional, competencia judicial internacional, jurisdicción, minimum contact test, desarrollo judicial.

Abstract: The new Spanish Act on International adoption («Ley 54/2007 de 28 de diciembre de adopción internacional») contains different provisions on international jurisdicion. Articles 14 and 15 face these topics with innovative perspectives. Jurisdiction of Spanish courts to establish international adoptions subsists only when the constitutional Minimum Contact Test is guaranteed. So Jurisdiction of the Spanish courts may be disregarded if the specific case does not present real connections with Spain. On the other hand, this new Spanish Act allows Spanish courts to modify international adoptions and to transform foreign simple adoptions into adoptions in the Spanish sense of this legal institution («adopción plena»). In general, this new Act 54/2007 contains creative solutions which may be useful to solve the intricate problems arose by international adoptions in a country like Spain, which receives thousands of adoption order made by foreign authorities and involving foreign children. 
Key words: International adoptions, international jurisdiction grounds, minimum contact test, judicial activism.

Sumario: I. Introducción.--II. Constitución de la adopción internacional en España por juez español: la «fase administrativa» previa. 1. Finalidad y carácter de la fase administrativa previa a la constitución de la adopción. 2. El condicionamiento de la competencia judicial internacional por los criterios de «competencia administrativa autonómica».III. Competencia judicial internacional para la constitución de la adopción internacional por juez español. 1. Foro de la residencia habitual del adoptando en España. 2. Foro de la nacionalidad española del adoptando. 3. Foro de la residencia habitual del adoptante en España. 4. Foro de la nacionalidad española del adoptante.-IV. Observaciones sobre los foros de competencia judicial internacional para la constitución de una adopción por juez español. 1. Amplitud de los foros de competencia judicial internacional. 2. Principio de vinculación mínima (Minimum Contact Test) y «cláusula de desvinculación judicial». 3. Momento temporal para la apreciación de la nacionalidad española y de la residencia habitual en España. 4. Competencia objetiva y territorial del órgano jurisdiccional para la constitución de la adopción internacional.-V. Competencia judicial internacional modificación, revisión, nulidad y conversión de la adopción en adopción plena. 1. Competencia judicial internacional para la declaración de nulidad de la adopción internacional. 2. Competencia judicial internacional para la conversión de la adopción simple en adopción plena. 3. Competencia judicial internacional para la modificación o revisión de una adopción.-VI. Competencia internacional de los cónsules españoles en materia de adopción internacional.-VII. Consideraciones finales.

\section{INTRODUCCIÓN}

1. La entrada en vigor, el 30 de diciembre de 2007, de la Ley 54/2007, de 28 de diciembre, de adopción internacional (BOE núm. 312 de 29 de diciembre de 2007, citada aquí como «LAI»), ofrece un panorama legal completamente renovado en la regulación jurídica de la adopción internacio-

${ }^{1}$ En torno a la Ley de adopción internacional de 28 diciembre 2007, vid. A.-L. CALvo Caravaca / J. CARrascosa González, La Ley 54/2007 de 28 de diciembre 2007 sobre adopción internacional (Reflexiones y comentarios), Comares, Granada, 2008. En torno al Proyecto de dicha Ley, vid. S. Álvarez GonZÁLEZ, «El proyecto de ley sobre adopción internacional: una crítica para sobrevivir a su explicación docente», Actualidad Civil, 2007, núm. 22, pp. 2597-2618; G. Esteban De LA Rosa (coord), Regulación de la adopción internacional. Nuevos Problemas. Nuevas soluciones, 2007. 
nal $^{1}$. Esta Ley constituye una valiosa muestra de una «legislación integral». Es una norma jurídica que aborda el régimen jurídico de la adopción internacional no sólo con las herramientas propias del Derecho internacional privado (= normas de competencia judicial internacional, Derecho aplicable y validez extraterritorial de decisiones), sino también con instrumentos legales de Derecho Civil, Procesal y Administrativo. La LAI es una «Ley integral sobre la adopción internacional» que parte arranca de la realidad de los fenómenos sociales actuales como fenómenos de alta complejidad que exigen una regulación a través de mecanismos legales de distinto alcance y carácter (= Derecho Privado y Derecho Público, Derecho sustantivo y Derecho Procesal, etc.), como ha sido subrayado (J. MÉNDEZ PÉREZ²).

2. Entre las cuestiones de Derecho internacional privado (= DIPr.) que incorpora la LAI, la determinación de la competencia de los tribunales españoles en las cuestiones relacionadas con la adopción internacional, adquiere una importancia de primer orden ${ }^{3}$.

\footnotetext{
2 J. MÉndez PÉREZ, La adopción, Bosch, Barcelona, 2000, p. 24, si bien en relación con la LOPJM 1/1996.

${ }^{3} \mathrm{La}$ doctrina española relativa a los aspectos de competencia judicial internacional en
} materia de adopción es abundante en número y rica en desarrollos. Vid. sin ánimo exhaustivo, S. ADROHER BIOSCA, «La adopción internacional: una aproximación general», en J. RODRÍGUEZ TORRENTE (ed.), El menor y la familia: conflictos e implicaciones, Madrid, 1998, pp. 229-304; S. ADROHER BiosCA, «Marco jurídico de la adopción internacional», AA.VV., Puntos capitales del Derecho de familia en su dimensión internacional, Dykinson, 1999, pp. 97-144; E. AlONSO CRESPO, Adopción nacional e internacional, Ed. La Ley, 2004; S. ÁlvAREZ GonZÁLEZ, «Adopción internacional y sociedad multicultural», Cursos de Derecho Internacional de Vitoria-Gasteiz, 1998, pp. 175-211; P. BRIOso DÍAZ, La constitución de la adopción en Derecho Internacional Privado, Madrid, Ministerio Asuntos Sociales, 1990; A.-L. CALvo CARAVACA, «Globalización y adopción internacional», en A.-L. CALVO CARAVACA / P. BLANCO-MoRALES Limones, Globalización y Derecho, Colex, Madrid, 2003, pp. 23-72; A.-L. CALVo CaraVACA / J. CARRASCOSA GONZÁLEZ, La Ley 54/2007 de 28 de diciembre 2007 sobre adopción internacional (Reflexiones y comentarios), Comares, Granada, 2008; M. A. CALzAdilla MEDINA, La adopción internacional en el Derecho español, Madrid, Dyinson, 2004; A. DURÁN AYAGO, «La filiación adoptiva en el ámbito internacional», La Ley, núm. 5272, 21 marzo 2001, pp. 3-14; J. M. ESPINAR VICENTE, El matrimonio y las familias en el sistema español de Derecho internacional privado, Civitas, Madrid, 1996, pp. 361-380; C. EsPlugues MotA, «El 'nuevo' régimen jurídico de la adopción internacional en España», RDIPP, 1997, pp. 3374; J. I. EsQuivias JARAmiLlo, La Adopción Internacional, Madrid, Colex, 1998; J. D. GoNZÁlEZ CAMPOS, «Filiación y alimentos», en J. D. GonZÁLEZ CAMPOS Y OTROS, Derecho internacional privado. Parte especial, 6. ${ }^{\text {a }}$ edición, 1995, pp. 366-375; M. GuZMÁn PeCES, La adopción internacional. Guía para adoptantes, mediadores y juristas, 2007; A. I. HERRÁN, La adopción internacional, Dykinson, Madrid, 2000; A. RoDRíGUEZ BENOT, «La filiación», en M. Aguilar Benítez DE Lugo y otros, Lecciones de Derecho civil internacional, Tecnos, Madrid, 2. ${ }^{\text {a }}$ ed., 2007, pp. 196-205; P. RodRÍGUEZ MATEOS, La adopción internacional, Oviedo, 1988; ID., «Adopción internacional», EJB, 1995, pp. 353-354; ID., «Art. 9.5 Cc.», Comentario al Cc. y Compilaciones Forales, 2. a ed., 1995, pp. 242-259; M. VIRGós / F. J. GARCIMARTín, Derecho procesal civil internacional. Litigación internacional, Civitas, Madrid, 2000, pp. 551-552. 


\section{CONSTITUCIÓN DE LA ADOPCIÓN INTERNACIONAL EN ESPAÑA POR JUEZ ESPAÑOL: LA «FASE ADMINISTRATIVA» PREVIA}

\section{Finalidad y carácter de la fase administrativa previa a la constitución de la adopción}

3. No debe nunca olvidarse que en Derecho español, la adopción es un acto de jurisdicción voluntaria cuya competencia está atribuida a los tribunales de justicia. La adopción se constituye, siempre, por un juez (= los jueces son los que toman, al final, la decisión de proceder o no a la adopción). Dicho esto, debe dejarse constancia de que, en principio, toda adopción que debe constituirse en España por un juez español se inicia con una «fase administrativa». Ello en nada afecta al hecho de que son los jueces los que «constituyen» la adopción (C. Esplugues Mota / J. L. Iglesias Buhigues ${ }^{4}$ ). En torno a la fase administrativa previa a la adopción cabe introducir ciertas observaciones.

4. a) Funciones de las Entidades Públicas y constitución de la adopción: propuesta previa de adopción internacional y declaración de idoneidad de los adoptantes. Las Entidades Públicas Administrativas competentes en materia de protección de menores realizan multitud de funciones de diferente alcance, que se encuentran relacionadas en el Capítulo II de la LAI (vid. especialmente el art. $5 \mathrm{LAI}^{5}$ ). Son funciones de información a los particulares impli-

${ }^{4}$ C. Esplugues Mota / J. L. Iglesias Buhigues, Derecho internacional privado, Ed. Tirant Lo Blanch, València, 2008, p. 352.

${ }^{5}$ Art. 5 LAI (Intervención de las Entidades Públicas de Protección de Menores). «En materia de adopción internacional corresponde a las Entidades Públicas competentes en materia de protección de menores: a) Organizar y facilitar la información sobre legislación, requisitos y trámites necesarios en España y en los países de origen de los menores, velando para que esa información sea lo más completa, veraz y actualizada posible y de libre acceso por los interesados. b) Facilitar a las familias la formación previa necesaria que les permita comprender y afrontar las implicaciones de la adopción internacional, preparándolas para el adecuado ejercicio de sus funciones parentales una vez constituida aquélla. Podrán delegar esta función en instituciones o entidades debidamente autorizadas. c) La recepción de las solicitudes, en todo caso, y su tramitación, ya sea directamente o a través de Entidades Colaboradoras de Adopción Internacional debidamente acreditadas. d) La expedición, en todo caso, de los certificados de idoneidad, previa elaboración, bien directamente o a través de instituciones o entidades debidamente autorizadas, del informe psicosocial de los solicitantes de la adopción, y, cuando lo exija el país de origen del adoptando, la expedición del compromiso de seguimiento. e) Recibir la asignación del menor, con información sobre su identidad, su adoptabilidad, su medio social y familiar, su historia médica y necesidades particulares; así como la información relativa al otorgamiento de los consentimientos de personas, instituciones y autoridades requeridas por la legislación del país de origen. f) Dar la conformidad respecto a la adecuación de las características del 
cados en la adopción, de facilitación de tramitación de la adopción internacional, de formación, apoyo técnico a adoptados y adoptantes, colaboración con los organismos públicos de los países de origen del menor, seguimiento de la adopción ya constituida, apoyo postadoptivo, etc. Ahora bien, en relación con la adopción internacional, esta fase administrativa previa comprende, necesariamente, dos elementos fundamentales.

1. $\left.{ }^{\circ}\right)$ Idoneidad de los adoptantes. La Entidad Pública debe acreditar la «idoneidad» de los adoptantes «para el ejercicio de la patria potestad» (art. 176 Cc.) (= la Entidad Pública debe acreditar su idoneidad para ser considerados «adoptantes»). La declaración de idoneidad puede ser anterior a la propuesta previa. A la hora de expedir esta «declaración de idoneidad», las autoridades administrativas competentes no valoran «extremos jurídicos» (= tales como la «capacidad para adoptar» de los potenciales adoptantes, la posible adopción por parte de parejas del mismo sexo, etc.). Las autoridades administrativas, simplemente, realizan, al emitir la «declaración de idoneidad», «una valoración psicosocial sobre la situación personal, familiar y relacional de los adoptantes, y su capacidad para establecer vínculos estables y seguros, sus habilidades educativas y su aptitud para atender a un menor en función de sus singulares circunstancias, así como cualquier otro elemento útil relacionado con la singularidad de la adopción internacional» (art. 10.2 LAI) (J. M. EsPinAR Vicente, M. GuZMÁn PECES ${ }^{6}$ ). Con otras pala-

niño asignado por el organismo competente del país de origen con las que figuren en el informe psicosocial que acompaña al certificado de idoneidad. A lo largo del proceso de adopción internacional ofrecerán apoyo técnico dirigido a los adoptados y a los adoptantes, prestándose particular atención a las personas que hayan adoptado menores con características o necesidades especiales. Durante la estancia de los adoptantes en el extranjero podrán contar para ello con la colaboración del Servicio Exterior. g) Los informes de los seguimientos requeridos por el país de origen del menor, que podrán encomendar a entidades como las previstas en el artículo 6 de esta Ley o a otras organizaciones sin ánimo de lucro. h) El establecimiento de recursos cualificados de apoyo postadoptivo para la adecuada atención de adoptados y adoptantes en la problemática que les es específica. i) La acreditación, control, inspección y elaboración de directrices de actuación de las Entidades Colaboradoras de Adopción Internacional que realicen funciones de intermediación en su ámbito territorial. En sus actuaciones en materia de adopción internacional, las Entidades Públicas competentes promoverán medidas para lograr la máxima coordinación y colaboración entre ellas. En particular, procurarán la homogeneización de procedimientos, plazos y costes».

${ }^{6}$ Un muy correcto entendimiento de la «idoneidad» se encuentra en J. M. EsPINAR VICENTE, «La modificación del art. $9.5 \mathrm{Cc}$. en el Proyecto de reforma sobre adopción», $R J$ La Ley, 1986, pp. 996-1002; ID., «La adopción de menores constituida en el extranjero y el reconocimiento de la patria potestad en España (algunas reflexiones en torno a la heterodoxa doctrina de la DGRN», AC, 1997, pp. 757-771; M. GuZMÁn PECES, La adopción internacional. Guía para adoptantes, mediadores y juristas, Ed. La Ley, Madrid, 2007, pp. 184187; ID., «La adopción internacional de menores: especial referencia al requisito de la idoneidad en el procedimiento de constitución», Anuario de la Facultad de Derecho de Alcalá de Henares, 2005-2006, pp. 83-105. Otra perspectiva, aunque referida a los casos en los que la idonedad se valora bajo la aplicación del CH 1993, puede verse en C. GonZÁLEZ 
bras, puede afirmarse que la «idoneidad» de los adoptantes no consiste en acreditar su «capacidad legal para adoptar» (= ya que ello deben realizarlo los jueces y tribunales), sino en una evaluación de su «capacidad, aptitud y motivación adecuadas para ejercer la patria potestad, atendiendo a las necesidades de los niños adoptados, y para asumir las peculiaridades, consecuencias y responsabilidades que conlleva la adopción internacional» (art. 10.1 LAI), como ha sido correctamente señalado (F. CALVo BABIO ${ }^{7}$ ), pese a los errores, habituales, que se observan en ciertos autores ${ }^{8}$.

2. $\left.{ }^{\circ}\right)$ Propuesta previa de adopción internacional. La Entidad Pública debe elaborar una «Propuesta administrativa previa» de adopción que se presenta posteriormente al juez y que «sugiere» al juez la adopción de un concreto menor por unos concretos adoptantes.

5. b) Carácter de esta fase de la adopción internacional. Esta fase presenta un carácter netamente administrativo. Las consecuencias de ello aparecen con claridad: $1 .^{\circ}$ ) Se trata de una fase regulada por normas de Derecho administrativo y se lleva a cabo por autoridades de la Administración, no por órganos judiciales. Por dicha razón, cuando estas Entidades Públicas colaboran con otras semejantes de los países de origen del menor, se trata de una colaboración «administrativa» internacional, regulada por normas de Derecho Administrativo y no de DIPr. (S. GARCÍA CANO ${ }^{9}$ ); $2^{\circ}{ }^{\circ}$ ) Al tratarse de una fase administrativa, el art. $8 \mathrm{Cc}$. es aplicable. Ello significa que esta fase debe observarse siempre que la adopción internacional se vaya a constituir en España por juez español, con independencia de la Ley estatal que rija la adopción (= que puede ser una Ley extranjera: vid. art. 21 LAI).

BEILfuss, «La aplicación en España del Convenio de La Haya de 29 mayo 1993 relativo a la protección del niño y a la cooperación en materia de adopción internacional», $R J C, 1996$, pp. 313-345; ID., «La entrada en vigor para España del Convenio de La Haya de 29 mayo 1993 relativo a la protección del niño y la cooperación en materia de adopción internacional», REDI, 1995 (II), vol. XLVII, pp. 485-488. Los términos de la polémica pueden verse muy bien ilustrados en M. HERRANZ BALLESTEROS, «La búsqueda de la armonía internacional de soluciones: ¿un objetivo a cualquier precio en materia de adopción internacional?», en A.-L. Calvo Caravaca / E. Castellanos Ruiz (Dir.), El Derecho de Familia ante el siglo XXI: aspectos internacionales, Colex, Madrid, 2004, pp. 487-510, p. 495.

${ }^{7}$ F. CALVo BABIO, «Reconocimiento en España de las adopciones constituidas en Rumanía: situaciones patológicas», La Ley, 1998-V, D-241, pp. 1585 ss.; ID., «Nota a la RDGRN 12 julio 1996», REDI, vol. XLIX, 1997-II, pp. 272-275.

${ }^{8}$ Es el caso de S. ÁlvAREZ GonZÁLEZ, «El proyecto de ley sobre adopción internacional: una crítica para sobrevivir a su explicación docente», Actualidad Civil, 2007, núm. 22, pp. 2597-2618.

${ }^{9}$ S. García CANo, Protección del menor y cooperación internacional de autoridades, Colex, Madrid, 2003, pp. 172-183. 
6. c) Identificación de estas «Entidades Públicas». Competencia autonómica y competencia estatal. La inmensa mayoría de las Entidades Públicas Administrativas competentes en materia de protección de menores son Entidades Públicas de las CC. AA. En efecto, las funciones públicas en materia de «protección de menores» han sido asumidas por las CC. AA. Resultado: cada C. A. dispone de sus propias autoridades competentes para intervenir en la fase administrativa previa de la adopción internacional. Cada Autoridad autonómica valora la «idoneidad de los adoptantes» y emite la «Propuesta previa de adopción». La relación de autoridades autonómicas competentes para llevar a cabo estas funciones, relación sumamente variable, puede obtenerse en numerosas páginas web y publicaciones especializadas.

7. d) Normas aplicables para la elaboración de la «propuesta previa de adopción» y para valorar la «idoneidad de los adoptantes». La LAI contiene una serie de normas mínimas y uniformes que regulan la elaboración de la propuesta previa de adopción y la expedición de la declaración de idoneidad de los adoptantes. Aparte de estas normas, las CC. AA. pueden establecer, como de hecho ha ocurrido, otras normas jurídicas que complementan las normas estatales en la regulación de ambos elementos. Las normas jurídicas autonómicas que regulan el régimen jurídico de la propuesta previa de adopción, de la idoneidad de los adoptantes y demás funciones que desarrollan las autoridades públicas autonómicas en relación con la adopción internacional, se aplican con sujeción al «principio de territorialidad» (= en el territorio de cada C. A., las autoridades de cada C. A. aplican exclusivamente sus normas administrativas relativas a estos extremos). Así se deduce del art. 8 Cc. aplicado por analogía y de los distintos Estatutos de Autonomía (= que recogen con claridad el carácter territorial del Derecho Público de cada C. A.).

\section{El condicionamiento de la competencia judicial internacional por los criterios de «competencia administrativa autonómica»}

8. Cada C. A. dispone de sus propios criterios de «competencia administrativa internacional» con arreglo a los cuales las autoridades públicas autonómicas pueden iniciar una «propuesta previa de adopción». En efecto, tales autoridades autonómicas no son competentes para expedir tal propuesta en todos los casos, sino sólo cuando los candidatos a adoptantes manifiesten una cierta «vinculación» con dicha C. A. Sin embargo, en este punto los criterios no son uniformes. Cada C. A. dispone de sus propios criterios competenciales. Es por ello por lo que, en ocasiones, son criterios «concurrentes» (= varias autoridades públicas de CC. AA. distintas pueden ser competentes para iniciar esta fase administrativa en relación con el mismo supuesto). Y, en otras ocasiones, la vinculación entre el supuesto y la C. A. competente para elaborar la propuesta previa y declaración de idoneidad no está garantizada. 
9. Estos criterios de «competencia administrativa previa» revisten una importancia decisiva, pues condicionan todo el procedimiento de adopción internacional, incluida la posterior y necesaria constitución judicial de la adopción. En efecto, si no concurre la «competencia administrativa internacional» de ninguna autoridad pública autonómica española, no será posible la posterior constitución de la adopción internacional ante juez español, incluso aunque los tribunales españoles resultaren competentes para constituir la adopción internacional a tenor de los arts. 14-17 LAI.

10. En general, cabe distinguir varios grupos de criterios de competencia administrativa para el inicio de esta fase administrativa de la adopción internacional: $1^{\circ}{ }^{\circ}$ ) Criterio de la residencia habitual de los adoptantes: en ciertas CC. AA., las autoridades autonómicas correspondientes son competentes para instruir esta fase administrativa si los adoptantes disponen de su residencia habitual en el territorio de la C. A. de la que se trate. Siguen este criterio, por ejemplo, Aragón (= art. 75.2 Ley 12/2001, 2 julio, de la infancia y la adolescencia); Cantabria (= art. 75.1 Ley 7/1999, de 28 abril, de protección de la infancia y la adolescencia); Navarra (= art. 74.1 Ley Foral 15/2005, de 5 de diciembre, de promoción, atención y protección a la infancia y a la adolescencia, que permite también, sin embargo, instar el procedimiento a sujetos sin residencia habitual en Navarra), etc. $2^{\circ} .^{\circ}$ Criterio de la mera residencia de los adoptantes. En otras CC. AA., las autoridades autonómicas correspondientes son competentes para instruir esta fase administrativa si los adoptantes tienen su mera «residencia» en el territorio de la C. A. de la que se trate. Siguen este criterio, por ejemplo, la C. A. de Canarias (= art. 73.1 Ley 1/1997, 7 febrero, de Atención Integral a los Menores y arts. 32 y 44 Decreto 54/1998 de 17 abril, actuaciones de amparo de los menores); Región de Murcia (= art. 9 Decreto 372/2007 de 30 noviembre 2007); Cataluña (= Ley 9/98 del Codi de Família); Galicia (= art. 32 Ley 3/1997, de 9 de junio, gallega de la Familia, la Infancia y la Adolescencia); Comunidad Valenciana (= art. 64 Decreto 93/2001, de 22 mayo, por el que se aprueba el Reglamento de Medidas de Protección Jurídica del Menor). $3^{\circ}{ }^{\circ}$ ) Criterio de la mera instancia. En otras CC. AA., las autoridades autonómicas correspondientes son competentes sólo con la mera presentación de la solicitud de adopción por parte de los adoptantes, sin que se exija que éstos presenten ninguna otra condición de vinculación con la C. A. en cuestión. Algunas CC. AA. encuadrables en este grupo indican que será un criterio preferente para el ofrecimiento de adopción el hecho de que los candidatos a adoptantes tengan su residencia habitual en la C. A. de que se trate. Es el caso de Asturias (= art. 16 Decreto 46/2000, de 1 de junio, por el que se aprueba el Reglamento de Acogimiento Familiar y de Adopción de Menores); La Rioja (= art. 104 Ley 1/2006, 28 febrero, de Protección de Menores de La Rioja); Castilla y León (=Ley 14/2002, de 25 julio, de promoción, atención y protección a la infancia); Comunidad de Madrid (= art. 59.1 Ley 6/1995, de 28 de marzo, de Garantías y derechos de la infancia y adoles- 
cencia); Extremadura (= art. 8.2 y 15 Decreto 5/2003, de 14 de enero, por el que se establece el procedimiento de valoración de las solicitudes de adopción y acogimiento familiar y de selección de adoptantes y acogedores); CastillaLa Mancha (= art. 56 Ley 3/1999, de 31 de marzo, del Menor).

\section{COMPETENCIA JUDICIAL INTERNACIONAL PARA LA CONSTITUCIÓN DE LA ADOPCIÓN INTERNACIONAL POR JUEZ ESPAÑOL}

11. Una vez emitida la propuesta previa por parte de la Entidad Pública española competente, la adopción internacional se constituye, necesariamente, por juez español «competente». Diversas advertencias previas resultan oportunas: $\left.1 .^{\circ}\right)$ Los foros de competencia judicial internacional en materia de adopción internacional se contienen en el art. 14 LAI (= constitución de la adopción), y en el art. 15 LAI (= modificación, revisión, declaración de nulidad o conversión en adopción plena de una adopción). 2..$^{\circ}$ ) Tales foros no son «foros exclusivos» en favor de los tribunales españoles. Eso significa que pueden surtir efectos jurídicos en España las adopciones constituidas por autoridades extranjeras sin que se pueda esgrimir en contra una pretendida «exclusividad de la jurisdicción española» en la materia (C. EsPLUGUES Mota / J. L. IgLesias BuHIGUES ${ }^{10}$ ). $3^{\circ}$ ) La LAI ha eliminado de raíz toda posibilidad de que la «sumisión de las partes» opere como foro de competencia judicial internacional en materia de constitución de la adopción. Se trata de una opción correcta de política legislativa. En efecto, la adopción es un acto de jurisdicción voluntaria y por ello, no existen, procesalmente hablando, dos «partes» con intereses opuestos que puedan acordar una sumisión a los tribunales españoles (C. Esplugues MotA ${ }^{11}$ ). 2. $^{\circ}$ ) La LAI ha eliminado también de raíz toda posibilidad de que el foro del «domicilio del demandado en España» opere en relación con la constitución de la adopción en España. Esta opción de política legislativa es también correcta, pues en los actos de jurisdicción voluntaria no existe ningún «demandado»(C. EsPlugues MOTA, J. M. Espinar Vicente, J. D. GonzÁlez Campos, A. Marín LóPeZ ${ }^{12}$ ). Otros

${ }^{10}$ C. Esplugues Mota / J. L. Iglesias Buhigues, Derecho internacional privado, Ed. Tirant Lo Blanch, València, 2008, p. 354.

${ }^{11}$ C. Esplugues Mota, «El 'nuevo' régimen jurídico de la adopción internacional en España», RDIPP, 1997, pp. 33-74, esp. p. 40.

12 J. M. ESPINAR VICENTE, El matrimonio y las familias en el sistema español de Derecho internacional privado, Civitas, Madrid, 1996, pp. 362-363 y nota [32]; C. EsPLugues MотA, «El 'nuevo' régimen jurídico de la adopción internacional en España», op. cit., pp. 33-74, esp. p. 40; J. D. GonZÁlez CAMPos, «Art. 9.5 Cc.», en Comentario del Código civil, Ministerio de Justicia, Madrid, 1991, p. 88; A. MARÍn LóPEZ, Derecho internacional privado I, 1994, 8. ${ }^{a}$ ed., pp. 208-209; A.-L. Calvo Caravaca / J. Carrascosa González, «Adopción internacional», en A.-L. Calvo Caravaca / J. Carrascosa González (Dirs.),

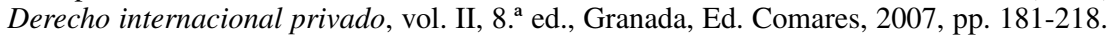


legisladores ya habían seguido esta mismo criterio radicalmente contrario a la operatividad de los foros de la sumisión de las partes y del domicilio del demandado (= vid. art. 66 Código belga de DIPr. 16 julio 2004 ${ }^{13}$ ).

12. Todos los foros de competencia judicial internacional contenidos en los arts. 14 y 15 LAI se refieren a la «adopción». Son, por tanto, inaplicables en relación con la kafalah del Derecho islámico clásico (A. RoDRíGUEZ Benot, M. A. Calzadilla Medina, J. Long, J. I. Esquivias Jaramillo, A. RODRÍGUEZ BENOT ${ }^{14}$ ). La presencia de la kafalah en Derecho musulmán está directamente relacionada con la expresa prohibición de la adopción en la cultura jurídica del Derecho islámico. En efecto, en el Derecho musulmán clásico no existe la adopción, que está prohibida por el Corán (versículos 4 y 5 de la Sura XXXIII ${ }^{15}$ ). Esta prohibición, como es sabido, tiene un origen muy polémico que se halla vinculado directamente con la vida del Profeta ${ }^{16}$. La

${ }^{13}$ Art. 66 Ley belga DIPr. 16 julio 2004: «Par dérogation aux dispositions générales de la présente loi, les juridictions belges ne sont compétentes pour prononcer une adoption que si l'adoptant, l'un des adoptants ou l'adopté est belge ou a sa résidence habituelle en Belgique lors de l'introduction de la demande».

${ }^{14}$ M. A. Calzadilla Medina, La adopción internacional en el Derecho español, Madrid, Dyinson, 2004, pp. 240-245; J. LoNG, «Adozione E Islam: Gli Ordinamenti giuridici occidentali e il divieto islamico di adozione», en Studi Urbinati di Scienze giuridiche, Politiche Ed. Economiche, 2003/04, pp. 55-65; ID., «Ordinamenti giuridici occidentali kafala e divieto di adozione: un'occasione per riflettere sull'adozione legittimante», en La nuova Giurisprudenza civile commentata, Marzo-Aprile 2003, pp. 33-45; J. I. EsQUIVIAS JARAMILLO, La Adopción Internacional, Madrid, Colex, 1998, pp. 173-177. Los estudios debidos a A. RodRíGuEZ BENOT sobre la kafalah musulmana son indispensables. Vid. A. RODRÍGUEZ BENOT, «Adopción y Kafala: un análisis de su alcance respectivo en los ordenamientos islámicos y occidentales», El Derecho internacional y las relaciones internacionales en el mundo mediterráneo, XVII Jornadas de la Asociación Española de Profesores de Derecho Internacional y Relaciones Internacionales, Madrid, 1999, pp. 195-206; A. RODRíGUEZ BENOT, «El reconocimiento de las medidas de protección del menor en un entorno multicultural. Un estudio comparado de la eficacia extraterritorial de la adopción y de la Kafala», $R G D$, núm. 667, 2000, pp. 4419-4447.

${ }^{15}$ Corán, Sura XXXIII: «4. Alá no ha puesto dos corazones en el pecho de ningún hombre. Ni ha hecho que las esposas que repudiáis por la fórmula: “¡Eres para mí como la espalda de mi madre!" sean vuestras madres. Ni ha hecho que vuestros hijos adoptivos sean vuestros propios hijos. Eso es lo que vuestras bocas dicen. Alá, empero, dice la verdad y conduce por el Camino. 5. Llamadles por su padre. Es más equitativo ante Alá. Y, si no sabéis quién es su padre, que sean vuestros hermanos en religión y vuestros protegidos. No incurrís en culpa si en ello os equivocáis, pero sí si lo hacéis deliberadamente. Alá es indulgente, misericordioso. 6. El Profeta está más cerca de los creyentes que ellos lo están de sí mismos. Las esposas de aquél son las madres de éstos. Los unidos por lazos de consanguinidad están más cerca unos de otros, según la Escritura de Alá, que los creyentes y los emigrados, a menos que hagáis un favor a vuestros amigos. Eso está anotado en la Escritura».

${ }^{16}$ Como muy ilustrativamente explica F. CALVo BABío, Reconocimiento en España de las adopciones simples realizadas en el extranjero, Univ. RJC, Dykinson, Madrid, 2003, pp. 13-15, parece ser que el origen de la prohibición de la adopción en el Derecho islámico clásico se halla en el siguiente hecho. Zayd era un varón que fue vendido como esclavo al 
kafalah se encuentra contemplada en la Shari'a (= conjunto de reglas para la vida del musulmán basado en diversas fuentes, como el mismo Corán, la Sunna, la Ijma y la Qiyyas). La kafalah del Derecho musulmán es una institución legal que no genera un «vínculo de filiación» entre el menor y sus «cuidadores» (kafils). El contenido y la finalidad de la kafalah son claros: la kafalah se limita a fijar una obligación personal en cuya virtud los «cuidadores» se hacen cargo del kafil y se obligan a atender su manutención y educación. La kafalah no rompe los lazos familiares sanguíneos y el estado familiar precedente del niño. El niño recibido mediante kafalah se beneficia de los cuidados materiales y de la educación proporcionados por su familia acogedora. Pero no dispone de derechos sucesorios en relación con su «nueva familia», ni existe vínculo de parentesco con dicha nueva familia (Res. Circular DGRN 15 julio 2006). Los titulares de la kafalah (kafils) no ostentan la patria potestad y por tanto, el sujeto sometido a kafalah no puede optar a la nacionalidad española a través del art. $20.1 \mathrm{Cc}$. (= posibilidad prevista para la persona sometida a la patria potestad de un español), ni tampoco adquiere la nacionalidad española a través del art. $19.1 \mathrm{Cc}$. (= sujeto adoptado por español) (RDGRN 21 marzo 2006, RDGRN [5.ㄹ 27 febrero 2006). La descripción jurídica de la kafalah puede seguirse en numerosos pronunciamientos de la jurisprudencia contemporánea española y extranjera (RDGRN 21 marzo 2006, RDGRN 14 mayo 1992, RDGRN 18 octubre 1993, RDGRN 14 mayo 1992, RDGRN 13 octubre 1995, RDGRN 1 febrero 1996, RDGRN [5. ${ }^{a}$ ] 27 febrero 2006, RDGRN [2. ${ }^{a}$ ] 21 marzo 2006, SAP Granada, Sec. 4. ${ }^{\text {a }}, 25$ abril 1995; Sent. Cour Cass Francia 10 octubre 2006; Sent. Corte Cassazione Italia 4 noviembre 2005). Debe advertirse que, sin embargo, la configuración concreta de la kafalah en los distintos países musulmanes es muy variable: algunos países no permiten una «kafalah internacional» (Irán, Mauritania, Egipto), otros sí las permiten siempre que los potenciales kafils sean de religión islámica (Marruecos, Pakistán, etc.), y otros países de tradición islámica admiten la adopción y la kafalah (Indonesia, Túnez ${ }^{17}$ ).

13. Por otra parte, debe recordarse que existe una serie de circunstancias que, aun cuando concurra algún foro de competencia judicial internacional

Profeta por unos mercaderes. El Profeta lo adoptó solemnemente ante la sagrada piedra negra de la Kaaba. Un día, el Profeta visitó a Zayd y no lo encontró en casa, pero sí halló en ella a Zeyned, su esposa, y quedó prendado de sus encantos. Zayd, conocedor de los deseos del Profeta, repudió a su esposa, de modo que el Profeta pudo contraer matrimonio con ella. Este matrimonio fue considerado por algunos como un incesto. La cuestión quedo solventada cuando Alá se apareció al Profeta y le indicó que no había incesto alguno, pues la adopción debía quedar prohibida, de modo que el matrimonio del Profeta con su nuera adoptiva ya no podía considerarse incestuoso.

${ }^{17}$ Información extraida de <www.iss-ssi.org $>$. 
en materia de adopción internacional, imposibilitan la constitución, modificación, nulidad o conversión de la adopción internacional por parte de las autoridades españolas. Tales circunstancias se encuentran recogidas en el art. 4 LAI (= «circunstancias que impiden o condicionan la adopción»). La finalidad de tales previsiones legales es (art. $4 \mathrm{LAI}$ ) evitar el tráfico de menores que se puede producir en situaciones de conflicto bélico y desastre natural, y en situaciones conectadas con Estados que no implementan controles públicos de garantía en las adopciones internacionales y/o que no respetan los principios jurídicos básicos internacionalmente reconocidos de la adopción de menores, con Estados cuyas prácticas y trámites de la adopción del menor no respetan el interés del menor, y con Estados en los que la adopción no salvaguarda los intereses en presencia de los progenitores, adoptandos o adoptantes. Por otro lado, existen también otras circunstancias que «condicionan» los trámites de una adopción internacional por las autoridades españolas (art. 4.2 y 4.-3 LAI).

14. Los Juzgados y Tribunales españoles serán competentes para la constitución de la adopción en los siguientes casos: a) cuando el adoptando sea español o tenga su residencia habitual en España; b) cuando el adoptante sea español o tenga su residencia habitual en España. Estos foros requieren un análisis detenido.

\section{Foro de la residencia habitual del adoptando en España}

15. Indica el art. 14.1.a) LAI que son competentes, para la constitución de adopción en supuestos internacionales, los Juzgados y Tribunales españoles «cuando el adoptando tenga su residencia habitual en España». Deben formularse varias precisiones relativas a este foro.

$\left.1 .^{\circ}\right)$ En este primer supuesto, la vinculación del supuesto con España es clara y se centra en las circunstancias presentes en el sujeto protagonista de la adopción, el adoptando, y que manifiestan una «vinculación estrecha» del supuesto con España. En efecto, en el caso de que el adoptando tenga en España su residencia habitual, la competencia de los jueces españoles está plenamente justificada: (a) España es el país en el que se encuentra el «centro social de vida del menor» (= España es el país en cuya sociedad el menor se encuentra integrado); (b) Son las autoridades españolas las autoridades «más cercanas al menor». Podrán recabar con extrema facilidad los datos e informaciones precisas para la adopción y podrán recibir de modo inmediato las declaraciones, consentimientos y asentimientos que exige la Ley para la constitución de la adopción. Por ambas razones, la competencia de los tribunales españoles es, en este caso, extremadamente «previsible» para todos los interesados. En suma, el foro de competencia judicial internacional basado en la residencia habitual del adoptando en España es una solución correcta de política legislativa porque reduce tanto los costes de información que 
derivan de la averiguación del tribunal competente en los casos internacionales, como reduce también los costes de litigación. Este foro sintoniza de modo exacto con el «principio de proximidad»: un foro de competencia judicial internacional es adecuado si potencia el acceso a los tribunales porque permite la litigación a costes reducidos. Proceder a la constitución de la adopción internacional en España cuando el adoptando tiene su residencia habitual en España es una solución que todos los sujetos implicados en la adopción internacional deben haber racionalmente previsto ex ante. Por ello, es una solución que comportará a todos esos sujetos, con gran probabilidad, costes más reducidos de los que comportaría la constitución de la adopción por autoridades de otros países.

$\left.2^{\circ} .^{\circ}\right)$ El concepto de «residencia habitual» es el recogido en la legislación española (art. $40 \mathrm{Cc}$.). Es irrelevante que el adoptando tenga su residencia habitual o su domicilio también en otros países con arreglo a la Ley de cualquier otro Estado. Sólo importa que el adoptando tenga su residencia habitual en España. Es también irrelevante, en este caso, la nacionalidad o nacionalidades que pudiera tener el menor.

\section{Foro de la nacionalidad española del adoptando}

16. Señala el art. 14.1.a) LAI que son competentes, para la constitución de adopción en supuestos internacionales, los Juzgados y Tribunales españoles «cuando el adoptando sea español». Distintas observaciones deben formularse en relación con este foro de competencia judicial internacional.

$1^{\circ}$ ) En el caso de que el adoptando sea español pero no tenga en España su residencia habitual, la conexión con España es más débil que en supuesto anterior. Sin embargo, en materias relativas a la persona, la nacionalidad es una circunstancia que manifiesta una vinculación que suele ser «real» y no «meramente aparente» entre el sujeto y el país del que es nacional. Por ello, este criterio hace que la competencia de los tribunales españoles sea también «previsible» para todos los interesados (= el juez español es un «juez próximo» al supuesto en el caso de adopción internacional de un español). De ese modo, este foro de competencia judicial internacional basado en la nacionalidad española del adoptando también permite reducir los costes de información que surgen en la determinación del tribunal competente en los casos de adopción internacional.

$2^{\circ} .^{\circ}$ ) Es irrelevante que el adoptando ostente varias nacionalidades. Si una de las nacionalidades que el adoptando tiene es la nacionalidad española, el foro de competencia judicial internacional operará. El art. 9.9 Cc. no es aplicable para determinar una «nacionalidad prevalente» a los efectos de precisar la competencia judicial internacional de los tribunales españoles en los casos de adoptando doble nacional.

3..$\left.^{\circ}\right)$ El art. 14 LAI emplea la expresión «ser español». Ello significa que el sujeto debe «ostentar» o «poseer» la nacionalidad española. En conse- 
cuencia, los sujetos que retienen la nacionalidad española de modo «latente» o «hibernada» en virtud de ciertos Convenios internacionales firmados por España, no «son» españoles y el art. 14 LAI no operará (RDGRN [2. $\left.{ }^{2}\right] 25$ marzo 2000). Debe tenerse en cuenta que, por efecto de ciertos Protocolos concluidos por España con países con los que ya tenía concertados Convenios de (falsa) doble nacionalidad, esta falsa doble nacionalidad se ha transformado en auténtica doble nacionalidad, al menos a ciertos efectos legales. En efecto, ciertos Protocolos indican que el sujeto puede poseer ambas nacionalidades de modo «activo». Ya no hay una «nacionalidad hibernada»: aunque estos ciudadanos quedan sometidos «a la legislación del país que otorga la nueva nacionalidad», es también cierto que se aplicará también a estas personas «la legislación de su nacionalidad primitiva» en todo lo que no sea incompatible con la legislación del país que otorga la nueva nacionalidad. Por tanto, y dentro de ciertos límites, ambas nacionalidades se pueden hacer valer, con lo que algunos de estos Convenios han pasado a ser, relativamente, «verdaderos Convenios de doble nacionalidad». Es el caso de los Protocolos firmados por España con Argentina, Colombia, Honduras, Paraguay, República Dominicana y Guatemala, y que modifican y alteran el significado de los originarios Convenios de doble nacionalidad. En este último supuesto, puede suceder que el sujeto sea un auténtico «doble nacional» y si una de las nacionalidades que ostenta es la nacionalidad española, el foro recogido en el art. 14.1.a) LAI es operativo.

\section{Foro de la residencia habitual del adoptante en España}

17. Indica el art. 14.1.b) LAI que son competentes, para la constitución de adopción en supuestos internacionales, los Juzgados y Tribunales españoles «cuando el adoptante tenga su residencia habitual en España». Este foro suscita interrogantes profundos. Por ello requiere una explicación más detallada. A primera vista, puede parecer que permite y admite la competencia judicial internacional de los tribunales españoles para constituir la adopción internacional en un caso sin vinculaciones suficientes con España. Sin embargo, se trata de una impresión engañosa. En efecto, existe una clara vinculación del supuesto con España. Al tener los adoptantes su residencia habitual en España, eso supondrá que tales adoptantes tienen en España su «centro social de vida» y con extrema frecuencia, será España el lugar en cuyo contexto y sociedad se integrará el adoptando. Se trata por tanto, de un foro de competencia judicial internacional «con proximidad anticipada» (= con frecuencia, este foro operará en favor de la «residencia habitual futura» del adoptando). Por esta razón, los sujetos implicados en la adopción pueden prever también, razonablemente, la competencia judicial internacional de los tribunales españoles para la constitución de la adopción internacional en este supuesto. Los costes de averiguación del tribunal competente y los costes de litigación ante los tribunales españoles serán, por ello, reducidos. 


\section{Foro de la nacionalidad española del adoptante}

18. Señala el art. 14.1.b) LAI que son competentes, para la constitución de adopción en supuestos internacionales, los Juzgados y Tribunales españoles «cuando el adoptante sea español». Este foro requiere ciertas consideraciones.

$\left.1 .^{\circ}\right)$ En apariencia, la vinculación del supuesto con España por la mera nacionalidad española del adoptante resulta débil. Sin embargo, este foro también refleja una vinculación real con España. La nacionalidad española del adoptante muestra que dicho sujeto se siente todavía vinculado con España, a cuya comunidad social no ha querido renunciar. Con frecuencia, la nacionalidad española del adoptante refleja la voluntad del dicho sujeto de no romper su ligamen con España y de dejar abierta la posibilidad de venir a vivir a España.

$2^{\circ} .^{\circ}$ ) Este foro permite cubrir casos en los que el adoptando se encuentra físicamente en España y el adoptante es español. Ejemplo: será posible la constitución de una adopción en España en el supuesto de un español que acaba de regresar a España procedente de un país extranjero en el que tenía asignada la custodia o la guarda de hecho de menor extranjero con residencia habitual en el extranjero.

\section{OBSERVACIONES SOBRE LOS FOROS DE COMPETENCIA JUDICIAL INTERNACIONAL PARA LA CONSTITUCIÓN DE UNA ADOPCIÓN POR JUEZ ESPAÑOL.}

19. La regulación contenida en el art. 14 LAI en torno a la competencia de los tribunales españoles para la constitución de adopciones internacionales suscita varias reflexiones.

\section{Amplitud de los foros de competencia judicial internacional}

20. Los foros de competencia judicial internacional retenidos por el art. 14 LAI son amplios. En consecuencia, el volumen de asuntos relativos a la constitución de adopciones que se atribuye a los tribunales españoles es elevado. Esta opción de política legislativa exige aclarar diversos aspectos.

$1^{\circ}$ ) La intención del legislador ha sido abrir la jurisdicción española de modo generoso, por una razón muy clara. Porque entiende que, con ello, se potencia la constitución de la adopción, que beneficia siempre al menor (J. D. GonZÁlez CAMPOS ${ }^{18}$ ). Unos foros de competencia judicial internacional

${ }^{18}$ J. D. GonzÁlez CAmpos, «Filiación y alimentos», en J. D. GonZÁlez CAmpos y otros, Derecho internacional privado. Parte especial, 6. ${ }^{a}$ edición, 1995, pp. 366-375, esp. p. 367: 
más restrictivos podían haber incurrido en perjuicio para el «interés del menor». Con foros de competencia judicial internacional muy amplios y estructurados, además, de modo alternativo, el legislador deja claro que el interés del menor aconseja garantizar, de un modo muy marcado, la posibilidad de constituir adopciones en España. Esta decisión del legislador debe ser valorada positivamente (M. VIRGós Soriano / F. J. GARCIMARTín AlFÉREZ, C. EsPlugues MotA ${ }^{19}$ ). En efecto, en principiom y con carácter general, el mayor beneficio legal que puede existir para un menor necesitado de protección, en el contexto internacional, es su «completa integración en una familia adecuada» para dicho menor mediante la figura de la adopción. Argumento: la adopción es la institución legal que presenta un grado mayor de integración familiar en un núcleo familiar (F. CALVo BABÍO ${ }^{20}$ ).

$\left.2 .^{\circ}\right)$ El legislador ha utilizado como foros de competencia judicial internacional en materia de adopción internacional, las «circunstancias subjetivas» de los individuos implicados en la adopción internacional (= nacionalidad y residencia habitual de tales sujetos), y no «circunstancias objetivas» de la relación jurídica. La explicación de este hecho radica en que, en las adopciones internacionales, las «personas» ocupan un lugar prevalente. Los criterios de atribución de competencia judicial internacional a los tribunales españoles se deben fundar, por ello, en circunstancias vinculadas a las personas (= nacionalidad y residencia habitual), que son las circunstancias relevantes que manifiestan la conexión de la adopción internacional con un país u otro (= en materia de adopción internacional, operan los «foros cercanos a la persona») (M. Virgós SoRIANo / F. J. GARCiMARTín ALFÉREZ $^{21}$ ). La utilización de circunstancias próximas a la persona como foros de competencia judicial internacional en materia de adopción inter-

«Por operar alternativamente la nacionalidad española junto a la residencia habitual del adoptante o adoptando, el volumen de competencia judicial internacional atribuido a los Jueces españoles es muy amplio. Lo que puede justificarse, sin duda, por el objetivo general de facilitar las adopciones, en interés de la infancia».

${ }^{19}$ M. Virgós Soriano / F. J. Garcimartín AlFéreZ, Derecho procesal civil internacional. Litigación internacional, 2. ${ }^{\text {a }}$ ed., Civitas, Madrid, 2007, p. 247; C. Esplugues MotA, «El 'nuevo' régimen jurídico de la adopción internacional en España», RDIPP, 1997, pp. 33-74, esp. p. 41.

${ }^{20}$ F. CAlvo Babío, Reconocimiento en España de las adopciones simples realizadas en el extranjero, Univ. RJC, Dykinson, Madrid, 2003, pp. 31-34. Vid. igualmente, A. BorRás RODRíGUEZ, El «interés del menor» como factor de progreso y unificación del Derecho internacional privado, Discurs d'ingrés Acadèmia de Jurisprudència i Legislació de Catalunya. Barcelona, 1993; J. RubeLlin-DEVICHI, «Le principe de l'intéret de l'enfant dans la loi et la jurisprudence française», Droit de l'enfance et de la famille, 1996-1, pp. 113-159; M. Herranz Ballesteros, El interés del menor en los Convenios de la Conferencia de La Haya de DIPr., Lex Nova, Valladolid, 2004, passim.

${ }^{21}$ M. Virgós Soriano / F. J. Garcimartín AlféreZ, Derecho procesal civil internacional. Litigación internacional, 2. ${ }^{\text {a }}$ ed., Civitas, Madrid, 2007, pp. 229-232. 
nacional permite identificar al tribunal competente con unos costes de transacción reducidos (= lo que potencia la constitución de las adopciones internacionales).

3..$\left.^{\circ}\right)$ La generosa apertura del acceso a los tribunales para la constitución de la adopción en los casos internacionales es una opción legislativa seguida también, por la razón antes aludida, en otros países (vid. art. 66.I de la Ley belga de 16 julio 2004 que contiene el Código de Derecho internacional privado $^{22}$ y art. 40 Ley DIPr. Italia $1995^{23}$ ), como explica la doctrina (R. BARAT$\mathrm{TA}^{24}$ ). Estos criterios alternativos y muy amplios de competencia judicial internacional eran ya los acogidos por el art. 23 LOPJ antes de la LAI.

\section{Principio de vinculación mínima (minimum contact test) y «cláusula de desvinculación judicial»}

21. Los cuatro foros de competencia judicial internacional recogidos en el art. 14 LAI, que operan con carácter alternativo, aparecen inspirados en el principio de «conexión mínima» (Minimum Contact Test). Por tanto, para poder constituir la adopción en España, es preciso realizar un «razonamiento en dos etapas»: $1 .^{\circ}$ ) En primer lugar, debe concurrir alguno de los foros recogidos en el art. 14 LAI (= «razonamiento en abstracto»). Estos foros están diseñados para los casos generales, los casos-tipo, los casos más normales, pues como escribía ULPIANO, Iura non in singulas personas, sed generaliter constituuntur ( = las normas no se elaboran para personas concretas, sino para todos)..$^{\circ}$ ) En segundo lugar, es necesario que, además, ninguno de esos foros opere, en el caso concreto, de modo «exorbitante» (= «razonamiento en concreto»). Es decir, es necesario que la competencia judicial internacional atribuida a los jueces españoles para la constitución de la adopción por cualquiera de los foros recogidos en el art. 14 LAI no se refiera a un supuesto específico que, realmente, no presenta una «conexión mínima» y «sustancial» con España. Sólo una «vinculación real» del caso concreto con España justifica la competencia judicial internacional de los tri-

\footnotetext{
${ }^{22}$ Art. 66 del Código belga de Derecho internacional privado (Ley de 16 julio 2004 que contiene el Código de Derecho internacional privado): «Par dérogation aux dispositions générales de la présente loi, les juridictions belges ne sont compétentes pour prononcer une adoption que si l'adoptant, l'un des adoptants ou l'adopté est belge ou a sa résidence habituelle en Belgique lors de l'introduction de la demande».

${ }^{23}$ Art. 40 Ley italiana de DIPr. de 31 mayo 1995: «Giurisdizione in materia di adozione. 1. I giudici italiani hanno giurisdizione in materia di adozione allorché: a) gli adottanti o uno di essi o l'adottando sono cittadini italiani ovvero stranieri residenti in Italia; $b$ ) l'adottando è un minore in stato di abbandono in Italia».

${ }^{24} \mathrm{R}$. BARATTA, «La giurisdizione italiana in materia di adozione di minori», RDI, 1988, vol. LXXI, pp. 48-85.
} 
bunales españoles. Así lo indica la Exposición de Motivos de la LAI ${ }^{25}$. Esta lectura de los arts. 14-15 LAI permite descubrir, de modo sencillo, que tales preceptos no contienen «foros exorbitantes» (M. GUZMÁN PECES).

22. Sin embargo, y para evitar efectos negativos de esta muy notable amplitud del volumen de adopciones internacionales que pueden constituir los tribunales españoles, estos foros de competencia judicial internacional recogidos en el art. $14 \mathrm{LAI}$ deben ser entendidos como «criterios retráctiles» de competencia judicial internacional (= en principio, operan tal y como están descritos en el art. 14.1 LAI, pero pueden «restringirse» o «retraerse» en casos específicos que no presentan una vinculación mínima con España). Es decir, los foros de competencia judicial internacional recogidos en el art. 14.1 LAI pueden y deben ser reducidos teleológicamente a través de un desarrollo judicial del art. 14 LAI (M. VIRGÓs Soriano / F. J. GARCIMARTín AlfÉrez, A.-L. Calvo CaravaCA ${ }^{26}$ ). Son foros que se justifican por la vinculación del supuesto con España. Ahora bien, dicha vinculación puede «fallar», en el caso concreto, lo que convertiría un foro razonable y usual, en un foro que opera, realmente, «de modo exorbitante». El art. $24 \mathrm{CE}$ y el art. 6 CEDH 1950 obliga a «expulsar» del sistema legal español todo «foro realmente exorbitante» (K.H. NADELMANN ${ }^{27}$ ). Los «foros exorbitantes» no respetan el «principio de previsibilidad de los tribunales competentes» (P. $\mathrm{HAY}^{28}$ ). Como escribe F. J. GARCIMARTín AlféreZ, «si el vínculo [que permite la competencia judicial internacional de nuestros tribunales] es manifiestamente irrazonable la norma es inconstitucional» ${ }^{29}$.

${ }^{25}$ Exposición de Motivos de la LAI (III): «Inspirada en el principio de 'conexión mínima', una autoridad española no debe proceder a la constitución, modificación o declaración de nulidad de una adopción internacional si el supuesto no aparece mínimamente conectado con España. De ese modo, se evita la penetración de foros exorbitantes en la legislación española, foros que pueden provocar la constitución de adopciones válidas en España pero ineficaces o inexistentes en otros países, especialmente en el país de origen del menor».

${ }^{26}$ M. Virgós Soriano / F. J. Garcimartín Alférez, Derecho procesal civil internacional. Litigación internacional, $2^{\mathrm{a}}$ ed., Civitas, Madrid, 2007, p. 247; A.-L. CAlvo CARAVACA, «Globalización y adopción internacional», en A.-L. CALvo CARAVACA / P. BLANCO-MoraLES Limones, Globalización y Derecho, Ed. Colex, Madrid, 2003, pp. 23-72; J. CARRASCoSA GonZÁLEZ, Desarrollo judicial y Derecho internacional privado, Comares, Granada, 2004, pp. 181-218.

${ }^{27}$ K. H. NAdelmanN, «Jurisdictionally improper fora», en Conflict of Laws, International and Intestate, The Hague, Martinus / Nijhoff, 1972, pp. 22-237.

${ }^{28}$ P. HAY, «Flexibility versus Predictability and Uniformity in Choice of Law», RCADI, 1991, vol. 226, pp. 281-412, esp. p. 310: «not requiring contacts in furtherance of such foreseeability, it therefore does not contribute to predictability».

${ }^{29}$ F. J. Garcimartín AlfÉREZ, «¿Caben reducciones teleológicas o abuso de derecho en las normas sobre competencia judicial internacional?», REDI, 1995 (II), vol. XLVII, pp. 121-136, esp. p. 123. 
23. El legislador ha preferido fijar unos foros de competencia judicial internacional muy amplios y permitir que los tribunales puedan «restringir» el alcance de tales foros a través de su desarrollo judicial. Esta opción es mejor que la contraria: establecer unos foros de competencia judicial internacional recortados y permitir que los tribunales los puedan «extender» a casos no previstos. Y la elección del legislador de la LAI es preferible porque la «argumentación explicativa» (= la motivación) que los jueces deben en todo caso proporcionar cuando llevan a cabo un desarrollo judicial del DIPr. es más sencilla cuando se trata de «restringir» el alcance de un foro de competencia judicial internacional, que cuando proceden a «crear» normas no escritas para aplicarlas a supuestos no contemplados. En efecto, la creación de normas directas de competencia judicial internacional por el juez supone una especie de «suplantación del legislador» que exige una «carga explicativa» mucho mayor que la restricción de una previsión legal a un grupo de supuestos más concretos que los previstos por la norma de competencia judicial internacional (= la clásica regla interpretativa Plus dixit quam voluit es más fácil de argumentar que la no menos clásica regla Minus dixit quam voluit, pues esta segunda regla exige «crear una norma», mientras que la primera no lo exige).

24. El legislador ha concedido una «autorización expresa» a los jueces para reducir el alcance de los foros de competencia judicial internacional del art. 14.1 LAI en casos concretos de adopción internacional que provocan infracción del principio de «vinculación mínima» del supuesto con España. Dicha autorización en favor de un «desarrollo judicial» del art. 14.1 LAI se encuentra en dos previsiones legales: (1) El art. 14.1 LAI comienza con una afirmación que presenta un significado claro (= «Con carácter general, los Juzgados y Tribunales españoles serán competentes para la constitución de la adopción en los siguientes casos....» [cursiva añadida]). Pues bien, la expresión «con carácter general» significa no sólo que los foros de competencia judicial internacional se refieren efectivamente a la competencia «internacional» de los tribunales españoles (= algo que ya se deduce claramente de la rúbrica del art. 14.1). Significa, además, y fundamentalmente, que la regla «general» experimenta «excepciones», y que los tribunales españoles están autorizados, en casos particulares, a «rechazar su competencia judicial internacional» si observan que les viene atribuido, ex art. 14.1 LAI, el conocimiento de un concreto supuesto de constitución de la adopción internacional que no presenta vinculaciones «reales» con España y que, por ello, puede perjudicar a los sujetos implicados, puede conducir a hacer competentes a los tribunales españoles de modo «imprevisible» y con elevados costes de transacción jurisdiccionales para los sujetos afectados y que puede dar lugar a una «adopción internacional claudicante» (= válida en España, cuyos tribunales pueden constituirla, pero sin efectos legales en otros países extranjeros conectados estrechamente con el caso). La expresión «con carác- 
ter general» con la que da inicio el art. 14.1 LAI significa que hay «excepciones» a los foros de competencia judicial internacional que a continuación se relacionan en dicho art. 14.1 LAI (= el art. 14 LAI es una «norma general» y precisamente por ello, presenta «excepciones»). Se trata de excepciones que se establecerán y se perfilarán por vía jurisprudencial, pues la Ley no puede recoger la infinidad de casos particulares que pueden surgir en la práctica en los que, aunque concurran foros de competencia judicial internacional en favor de los tribunales para la constitución de la adopción internacional, el supuesto concreto no está, realmente, vinculado con España de modo suficiente o mínimo (= son foros que concurren sólo «formalmente», pero no representan una conexión real o «sustancial» con España). (2) La Exposición de Motivos de la LAI contiene un mandato muy claro dirigido a los jueces y tribunales españoles. Éstos no deben proceder a la constitución de una adopción internacional si el supuesto no aparece mínimamente conectado con España pese a concurrir, «formalmente», un foro de competencia judicial internacional recogido en la $\mathrm{LAI}^{30}$.

25. Así pues, a pesar de que concurra uno de los foros previstos en el art. 14 LAI, los tribunales españoles estarán autorizados a activar una «cláusula de desvinculación» por vía de un desarrollo judicial, que les permitirá no proceder a la constitución de una adopción internacional «si el supuesto no aparece mínimamente conectado con España» (Exposición de Motivos LAI, [III]). Esta «cláusula de desvinculación» evita los efectos indeseables que producen los foros exorbitantes y se justifica por estas razones: (a) Evita la vulneración del derecho constitucional de tutela judicial efectiva de los interesados (art. 24 CE). (b) Reduce los costes de información judicial de los interesados, que no se verán «atraídos» hacia los tribunales españoles, cuya competencia judicial internacional nunca habrían podido prever, si el caso no presentara un contacto mínimo y real con España. Obligarles a acudir a éstos provocaría un aumento de los costes de litigación y de los costes de determinación del tribunal competente. (c) Impide, con frecuencia, la constitución de adopciones claudicantes (= adopciones válidas en España pero ineficaces o inexistentes en otros países, especialmente en el país de origen del menor). Las adopciones claudicantes vulneran, con carácter general, el interés del menor. En este sentido, los jueces españoles deben rechazar su propia competencia judicial internacional si, tras un examen detenido de la «recognoscibilidad» en el país extranjero de la adopción internacional a constituir en

${ }^{30}$ Exposición de Motivos LAI (III): «Inspirada en el principio de "conexión mínima", una autoridad española no debe proceder a la constitución, modificación o declaración de nulidad de una adopción internacional si el supuesto no aparece mínimamente conectado con España. De ese modo, se evita la penetración de foros exorbitantes en la legislación española, foros que pueden provocar la constitución de adopciones válidas en España pero ineficaces o inexistentes en otros países, especialmente en el país de origen del menor». 
España, se observa que, efectivamente, dicha adopción no surtirá efectos legales en dicho país ( $=$ en línea con lo sostenido por la práctica y doctrina alemana: «técnica elástica» ${ }^{31}$ ). Esta «cláusula de desvinculación» permitirá que el juez español no se declare internacionalmente competente, por ejemplo, en el caso de que la nacionalidad española del adoptante o del adoptando sea una «nacionalidad no efectiva» que el sujeto «ostenta» pero no «utiliza» y la nueva familia en la que el adoptando se integra ni tiene su residencia habitual España ni muestra intención de tenerla en el futuro.

26. Un ejemplo ayudará a percibir la interacción entre los foros de competencia judicial internacional previstos en el art. $14 \mathrm{LAI}$ (= formulados para los «casos-tipo», que son necesariamente, los casos «normales» y «generales») y la creatividad judicial en forma de un desarrollo de los principios sustentadores de la LAI en la materia (= prevista para los casos más complejos, Hard Cases). Se insta ante juez español la constitución de la adopción de un menor eslovaco residente en Eslovaquia por parte de un varón español y de una mujer eslovaca residentes ambos en Eslovaquia, personas que no tienen ninguna intención de venir a residir a España. Además, el español ostenta también la nacionalidad eslovaca y no utiliza en su vida cotidiana su nacionalidad española. Formalmente, concurre un foro de competencia judicial internacional: la «nacionalidad española» de uno de los adoptantes. Pero si se observa el caso con detenimiento, se aprecia que el vínculo del caso con España, formalmente existente, es sustancialmente inexistente (= no refleja una auténtica conexión del caso con España). Por ello, este foro podría funcionar como un foro exorbitante, lo que es contrario al art. $24 \mathrm{CE}$. En consecuencia, el juez español no debe considerarse internacionalmente competente para constituir esta adopción. Es más lógico que la adopción se constituya en Eslovaquia con arreglo al DIPr. de ese país o que se constituya ante el Cónsul español acreditado en dicho país, si ello es posible. En el caso de que el juez español acredite que no es intención de la familia trasladarse a residir a España y que la adopción que podría constituir en España tiene muchas posibilidades de no surtir efectos legales en Eslovaquia, haría bien en declarar la falta de competencia judicial internacional de los jueces españoles para constituir esta adopción, y todo ello, mediante un desarrollo judicial del art. 14 LAI. De ese modo, evitaría que dicho precepto opere como un foro exorbitante y evitaría constituir una adopción internacional válida en España pero muy probablemente nula en Eslovaquia (= país de residencia habitual del menor y donde vive su familia adoptiva). Lo que a su vez, evitaría una adopción en España que generaría unos costes jurisdiccionales muy elevados para todos los sujetos afectados.

${ }^{31}$ E. JAYME, «Diritto di famiglia, societa multiculturale e nuovi sviluppi del Diritto internazionale privato», RDIPP, 1993, pp. 295-304; E. JAYME, «L'adozione internazionale. Tendenze e riforme», Rivista di Diritto Civile, 1984, pp. 545-558. 


\section{Momento temporal para la aprecicación de la nacionalidad española y de la residencia habitual en España}

27. En relación con todos los foros de competencia judicial internacional contemplados en el art. 14 LAI, la nacionalidad española y la residencia habitual en España de adoptante y/o adoptando deben quedar acreditadas en el momento de la presentación de la solicitud de adopción a la Entidad Pública competente (art. 14.2 LAI). Esta fijación del momento temporal refuerza la seguridad jurídica y había sido ya defendida por la jurisprudencia (AAP Madrid 27 julio 2006 [adoptante español]), por la DGRN (Res. Circular DGRN 15 julio 2006, en BOE núm. 207 de 30 agosto 2006) y por la doctrina (E. RodríGuez GAYÁN, J. D. GonZÁlez CAMPOS ${ }^{32}$ ).

\section{Competencia objetiva y territorial del órgano jurisdiccional para la constitución de la adopción internacional}

28. El art. 16 LAI indica qué precisión del concreto órgano jurisdiccional competente objetiva y territorialmente para la constitución de la adopción internacional se llevará a cabo con arreglo a las normas de la jurisdicción voluntaria. Varias reflexiones son precisas sobre la cuestión.

$\left.1 .^{\circ}\right)$ Esta remisión en favor de las «normas de la jurisdicción voluntaria» tenía como objetivo final las normas contenidas en la non nata Ley de la Jurisdicción Voluntaria que se tramitó durante la legislatura 2004-2008. Pero dicha Ley nunca vio la luz como tal y el Proyecto de Ley quedó en eso, en un Proyecto arrumbado, con destino incierto, en algún cajón del Congreso de los Diputados. Por tanto, la referencia que se contiene en el art. 16.1 LAI debe entenderse hecha en favor del art. 63.16 LEC 1881, precepto que sigue en pleno vigor tras el fracaso de la Ley anteriormente mencionada ${ }^{33}$.

2. $\left.{ }^{\circ}\right)$ Por tanto, será juez español territorialmente competente el juez correspondiente al domicilio de la Entidad Pública que hace la propuesta de adopción, y en su defecto, el juez del domicilio del adoptante.

3..$^{\circ}$ ) En el caso de que a través de dicho precepto no pueda identificarse un juez territorialmente competente, porque no existe propuesta previa de una Entidad pública española y porque, además, los adoptantes no están

32 E. RodríGuez GAYÁn, Derecho Registral Internacional, Madrid, Eurolex, 1995, p. 146. J. D. GonZÁLEZ CAMPOS, «Filiación y alimentos», en J. D. GonZÁlEZ CAMPOS y OTROS,

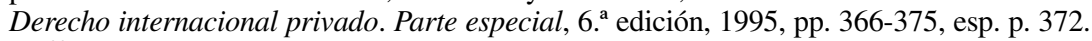

${ }^{33}$ Art. 63.16 LEC 1881: «Para determinar la competencia, fuera de los casos expresados en los artículos anteriores, se seguirán las reglas siguientes: (...) 16. En las actuaciones judiciales sobre acogimiento familiar o adopción o en las relacionadas con las funciones de protección encomendadas a las correspondientes entidades públicas, será competente el Juez del domicilio de la entidad y, en su defecto, el del domicilio del adoptante. En las actuaciones judiciales a que se refieren los artículos 179 y 180 Código Civil. Será competente el Juez del domicilio del adoptante». 
domiciliados en España, será tribunal territorialmente competente el órgano judicial que los adoptantes libremente elijan (art. 16.2 LAI). Sigue aquí el art. 16.2 LAI la llamada «solución francesa», defendida en dicho país (H. BATIFFol, A. Heldrich, P.H. Neuhaus) y también por la doctrina española (J. D. GONZÁLEZ CAMPOS ${ }^{34}$ ).

\section{COMPETENCIA JUDICIAL INTERNACIONAL, MODIFICA- CIÓN, REVISIÓN, NULIDAD Y CONVERSIÓN DE LA ADOP- CIÓN EN ADOPCIÓN PLENA}

29. El art. 22.3 LOPJ no contenía ningún criterio para determinar la competencia judicial internacional en relación con la extinción o nulidad de la adopción, ni con su revisión o modificación, ni con la conversión de una adopción simple en adopción plena. Sólo se preveía la competencia judicial internacional de los tribunales españoles "para la constitución de la adopción» (art. 22.3.5. ${ }^{\circ}$ LOPJ). Ante la laguna legal, la jurisprudencia se mantenía indecisa (erróneamente: AAP Madrid 25 enero 2002). De modo muy correcto, la DGRN entendió que los foros de competencia judicial internacional previstos en el art. 22.3 LOPJ para la «constitución de la adopción» en favor de los tribunales españoles debían aplicarse, por analogía, para determinar la competencia de los tribunales españoles en relación con la modificación y con la declaración de nulidad de la adopción (correctamente: ConDGRN 19 noviembre 2003 [adopción presuntamente irregular de menor ruso en España]), como había también defendido parte de la doctrina (A.-L. Calvo Caravaca / J. Carrascosa González ${ }^{35}$ ). La LAI acaba con esta lamentable situación y proporciona soluciones claras, racionales y sistemáticas a estas cuestiones. El legislador español de la LAI ha tomado estos foros del art. 66 de la Ley belga de 16 julio 2004 (= Ley que contiene el Código de Derecho internacional privado).

${ }^{34}$ A. HELDRICH, Internationale Zuständigkeit und Anweendbares Recht, Walter de Gruyter \& Co., Berlín, JCB Mohr, Tubinga, 1969, pp. 36-39; P. H. NeuHaus, «Internationales Zivilprozessrecht und Internationales Privatrecht», RabelsZ., 1955, pp. 240-260; H. BATIFFOL, «Observations sur les liens entre la compétence judiciaire et la compétence legislative», De conflictu Legum. Mélanges offerts à R.D.Kollewijn / J.Offerhaus, Leyden, Sijthoff, 1962, pp. 5-24; J. D. GonZÁlez CAmpos, «Filiación y alimentos», en J. D. GonZÁlez Campos y OTROS, Derecho internacional privado. Parte especial, 6. ${ }^{\text {a }}$ edición, 1995, pp. 366-375, esp. pp. 372-373.

35 A.-L. Calvo Caravaca / J. Carrascosa González, «Adopción internacional», en A.L. Calvo Caravaca / J. Carrascosa González (Dirs.), Derecho internacional privado, vol. II, 8. ${ }^{a}$ ed., Granada, Ed. Comares, 2007, pp. 181-218. 


\section{Competencia judicial internacional para la declaración de nulidad de la adopción internacional}

30. En lo relativo a la competencia judicial internacional para la declaración de nulidad de una adopción en supuestos internacionales, varios aspectos deben ponerse de relieve.

$\left.1 .^{\circ}\right)$ Los foros de competencia judicial internacional que permiten a los tribunales españoles declarar la nulidad de una adopción son los siguientes (art. 15.1 LAI): a) Adoptado español o con residencia habitual en España en el momento de presentación de la solicitud. b) Adoptante español o con residencia habitual en España en el momento de presentación de la solicitud. c) Adopción constituida por autoridad española.

$\left.2 .^{\circ}\right)$ La nulidad de la adopción puede venir establecida por la Ley española (art. 18 LAI y art. 180.2 Cc.), o bien puede venir contemplada por la Ley extranjera correspondiente que regule la cuestión a tenor de los arts. 21 y 22 LAI.

\section{Competencia judicial internacional para la conversión de la adopción simple en adopción plena}

31. La expresión «adopciones simples» cubre una realidad muy extensa de tipos de adopción con notables diferencias entre sí (F. CALvo BABío, C. A. LóPEZ DE ZAVALíA ${ }^{36}$ ). A la hora de convertir una adopción simple en una adopción plena, existe un amplio abanico de posibilidades: (a) Pueden instar la conversión de una adopción simple en una adopción plena ante las autoridades extranjeras y con arreglo a las normas de DIPr. extranjeras del país que corresponda. (b) Pueden también instar ex novo la constitución de una adopción plena «española» en relación con un sujeto que ha sido adoptado en forma simple o menos plena en un país extranjero (= opción interesante en el caso de que el Derecho extranjero regulador de la adopción simple no permita su conversión en una adopción plena, aunque la nueva adopción plena española no producirá muy probablemente, efectos legales en el país extranjero). (c) Los interesados pueden instar, ante los tribunales españoles, la conversión de la adopción simple en una adopción plena «extranjera» (= según las previsiones de un Derecho extranjero). (d) Pueden igualmente los interesados instar la conversión de la adopción simple o menos plena en una «adopción plena española» con arreglo al procedimiento específico previsto en el art. 30.4 LAI.

${ }^{36}$ Vid. el magnífico y muy completo estudio de F. CALvo BABío, Reconocimiento en Espa$\tilde{n} a$ de las adopciones simples realizadas en el extranjero, Univ. RJC, Dykinson, Madrid, 2003, esp. pp. 97-154. Vid. también, C. A. LÓPEZ DE ZAVALÍA, «Adopción simple internacional: una visión desde el punto de vista de la tolerancia y en favor de los intereses superiores del niño», Revista general de legislación y jurisprudencia, núm. 3, 2005, pp. 369-400. 
32. El art. 1.2 LAI incluye, sin duda ninguna, en el concepto de «adopción internacional», tanto la adopción plena como la adopción simple. En consecuencia, las reglas sobre competencia judicial internacional para la constitución, revisión, y nulidad de la adopción contenidas en los arts. 14-17 LAI son aplicables a la adopción simple. A efectos de la LAI, se entiende por «adopción simple o menos plena» aquella constituida por autoridad extranjera competente cuyos efectos no se correspondan sustancialmente con los previstos para la adopción en la legislación española (art. 15.4 LAI). Estos foros se proyectan sobre dos procedimientos distintos: (a) Conversión de la adopción simple o menos plena en una «adopción plena española» con arreglo al «procedimiento específico» previsto en el art. 30.4 LAI. (b) Conversión de la adopción simple en una adopción plena «extranjera» (= según las previsiones de un Derecho extranjero).

33. Los foros de competencia judicial internacional de los tribunales españoles para la conversión de una adopción simple en adopción plena son los que siguen (art. 15.2 LAI): (a) Adoptado español o con residencia habitual en España en el momento de presentación de la solicitud. (b) Adoptante español o con residencia habitual en España en el momento de presentación de la solicitud. (c) Adopción constituida por autoridad española. Pueden igualmente los interesados instar la conversión de la adopción simple o menos plena en una «adopción plena española» con arreglo al procedimiento específico previsto en el art. 30.4 LAI. (d) Pueden también instar ex novo la constitución de una adopción plena «española» en relación con un sujeto que ha sido adoptado en forma simple o menos plena en un país extranjero (= opción interesante en el caso de que el Derecho extranjero regulador de la adopción simple no permita su conversión en una adopción plena, aunque la nueva adopción plena española no producirá muy probablemente, efectos legales en el país extranjero). El «contacto» de la adopción simple con la esfera jurídica española (= garantizado por la concurrencia de un foro de competencia judicial internacional en el momento en el que se solicita la conversión de la adopción simple en plena), asegura que la adopción simple a transformar en adopción plena está «integrada» en la sociedad española. Por tanto, España no se convierte, automáticamente, en un «país-oasis» para la conversión de todas las adopciones simples del mundo en adopciones plenas ( $=$ si no concurre ningún foro de competencia judicial internacional recogido en el art. 15 LAI, la transformación de la adopción simple en adopción plena por las autoridades españolas resulta imposible).

34. Como se observa, se trata de los mismos foros de competencia judicial internacional ya previstos para la constitución de la adopción internacional en España, a los que se suma «un foro más». Este «foro añadido» es, en concreto, el hecho de que se trate de una adopción «no plena» constituida por 
las autoridades españolas. Tras la Ley 21/1987, no cabe en Derecho español ya la adopción «simple» o «menos plena», sino sólo la adopción plena, salvo en ciertos supuestos muy excepcionales ${ }^{37}$. Sin embargo, debe indicarse al respecto que los tribunales españoles pueden constituir adopciones con arreglo a Leyes extranjeras que admitan adopciones «simples» o «no plenas» (art. 21 LAI).

35. Para facilitar la adopción plena «española» del adoptado en forma simple «extranjera», el art. 30.4.I in fine y II LAI disponen lo siguiente: a) La adopción simple o menos plena será considerada como un «acogimiento familiar» (= aunque sólo a los efectos de su conversión en una adopción plena española, puesto que si ése no es el objetivo perseguido, la adopción simple surte en España los efectos de una adopción simple, y no de un «acogimiento familiar»: art. 30.1 y 2 LAI). b) Para instar el correspondiente expediente judicial no será necesaria la propuesta previa de la Entidad Pública competente. Este paso ahorra toda la «fase administrativa» que es exigible, en principio, a las adopciones que se constituyen ante autoridad española (art. 176 Cc.). La DGRN ya había observado las ventajas de considerar una adopción simple como un «acogimiento familiar de tipo español» a los solos efectos de su conversión en adopción plena. La referencia que hace el art. 30.4.I LAI a esta equiparación entre instituciones legales debe ser entendida, como se ha avanzado, en el sentido de que tal equiparación se realiza a los solos efectos de la posterior conversión de la adopción simple «extranjera» en adopción plena «española».

36. Por otra parte, resulta conveniente recordar que las normas de conflicto recogidas en los arts. 18-23 LAI señalan la Ley aplicable tanto a la adopción plena como a la adopción simple. En el caso de que el adoptando tenga su residencia habitual presente o futura en España, la Ley que rige la adopción es la Ley sustantiva española, por lo que no cabrá constituir una adopción simple por juez español (= esa adopción se integra en la sociedad española y la sociedad española se rige por la Ley española, que no admite la adopción simple). En el caso de que el adoptando tenga su residencia habitual presente fuera de España y no vaya a ser trasladado a España para fijar su residencia habitual en España, la adopción se regirá por una Ley extran-

${ }^{37}$ Art. 178 Cc.: «1. La adopción produce la extinción de los vínculos jurídicos entre el adoptado y su familia anterior. 2. Por excepción subsistirán los vínculos jurídicos con la familia del progenitor que, según el caso corresponda: $1 .{ }^{\circ}$ Cuando el adoptado sea hijo del cónyuge del adoptante, aunque el consorte hubiere fallecido. $2{ }^{\circ}$ Cuando sólo uno de los progenitores haya sido legalmente determinado, siempre que tal efecto hubiere sido solicitado por el adoptante, el adoptado mayor de doce años y el progenitor cuyo vínculo haya de persistir. 3. Lo establecido en los apartados anteriores se entiende sin perjuicio de lo dispuesto sobre impedimentos matrimoniales». 
jera (= pues dicha adopción afecta a la sociedad «extranjera», no a la sociedad «española»). Si en dicha Ley se contempla la adopción simple, el juez español podrá constituir dicha adopción simple. El juez español podrá, sin embargo, rechazar la constitución de tal adopción simple regida por una Ley extranjera si considera que dicho ordenamiento produce consecuencias contrarias al orden público internacional español y, en particular, porque la adopción simple no encaje con el interés superior del menor (= ya que puede observarse que la adopción simple podría perjudicar al menor si otra institución de protección de éste le resulta más conveniente). La posibilidad de constituir una adopción plena por parte de autoridades españolas es lógica, pues si se permite que tengan eficacia legal en España las adopciones simples como tales «adopciones simples», resulta difícil negar la constitución en España de tales adopciones simples cuando una Ley extranjera así lo determine ${ }^{38}$.

\section{Competencia judicial internacional para la modificación o revisión de una adopción}

37. Los foros de competencia judicial internacional que permiten a los tribunales españoles modificar o revisar una adopción internacional son los que siguen (art. 15 LAI): a) Adoptado español o con residencia habitual en España en el momento de presentación de la solicitud. b) Adoptante español o con residencia habitual en España en el momento de presentación de la solicitud. c) Adopción constituida por autoridad española.

38. En el caso de modificación de una adopción constituida por autoridad extranjera, dicha adopción debe haber sido «reconocida en España» a través los mecanismos legales establecidos. Los tribunales españoles pueden modificar o revisar resoluciones extranjeras de adopción. Ello no supone ninguna lesión de la Soberanía del Estado cuyos tribunales dictaron la sentencia originaria. El Derecho español guarda silencio absoluto en torno a la necesidad o no necesidad de un previo «reconocimiento» de la sentencia extranjera a modificar por los tribunales españoles. El art. 15 LAI exige tal previo «reconocimiento». El precepto sigue, así, la tesis de los tribunales que habían exigido, para poder modificar la sentencia extranjera, que ésta hubiera ganado en España su previo reconocimiento (AAP Castellón 13 septiembre 2005, AAP Madrid 30 noviembre 2005). Argumento: sólo puede modificarse la sentencia extranjera que ha surtido en España los «efectos constitutivos».

${ }^{38}$ Sobre la cuestión, vid. J. M. ESPINAR VICENTE, El matrimonio y las familias en el sistema español de Derecho internacional privado, Civitas, Madrid, 1996, p. 370. 
39. Existen muy buenas razones para la presencia de este art. 15.3 LAI, algunas de las cuales pueden sintetizarse en las siguientes: $1 .^{\circ}$ ) Los conceptos de «anulación», «nulidad», «revisión» y «revocación» de la adopción presentan un alcance muy distinto en los diferentes Derechos estatales (R. Espinosa CAlABUig, D. OpertTi BADAN ${ }^{39}$ ). Por ello, el art. 15 LAI ha recogido foros de competencia judicial internacional en materia de revisión o modificación de la adopción, nulidad y conversión de ésta. El objetivo es claro: que no pueda excluirse la competencia judicial internacional de los tribunales españoles por ejercitar una acción para la que no hay previsto un foro específico de competencia judicial internacional en el DIPr. español. 2. ${ }^{\circ}$ ) La «revisión» de una resolución sobre adopción puede ser perfectamente posible en Derecho extranjero. Así ocurre en Derecho belga: el art. 351 del Código Civil belga, en redacción dada por el art. 2 de la Ley de 24 abril 2003, aplicable a partir del 1 septiembre 2005, contempla la revisión de la adopción, ya que en Derecho belga, «la adopción no puede ser atacada por vía de nulidad» (art. 349.3 Código civil belga). Lo que existe es una «revisión de la adopción», no una posible declaración de «nulidad» de la adopción (= vid. también, en sintonía con ello, el art. 66.IV Código belga de DIPr de 16 julio $2004^{40}$ ). En determinados Derechos extranjeros, la revisión de la adopción puede ser equivalente a lo que en Derecho español es la declaración de «nulidad de la adopción». Pero no tiene por qué ser así. En efecto, debe recordarse que, de nuevo en Derecho belga, la revisión de la adopción produce efectos ex nunc y no efectos ex tunc, que son los propios de la declaración de nulidad de una adopción y que las causas por las que una adopción puede ser objeto de «revisión» son diferentes de las causas por las que puede ser declarada, en su caso, su nulidad (vid. art. 351 in fine Código civil belga). $3^{\circ}$ ) El art. 15.3 LAI es también una «norma prospectiva», que regula la competencia judicial internacional de los tribunales españoles para casos de revisión o modificación de la adopción que puedan establecerse en Derecho español o en otro Derecho extranjero en España en el futuro. $4 .^{\circ}$ ) Existe en la actualidad una tendencia a regular las «obligaciones post-adoptivas» de los adoptantes. Pues bien, en previsión de futuro, el art. 15.3 LAI contempla la «modificación de la adopción» para cubrir los casos en los que el tribunal pueda o deba «alterar» $\mathrm{o}$ «perfilar» estas obligaciones post-adoptivas asumidas por los adoptantes.

${ }^{39}$ R. EsPinOSA CALABUiG, «Una nueva reforma en materia de adopción internacional en España», $R G D$, 2000, n. 667, pp. 4344-4361, esp. p. 4352; D. OPERTTI BADAN, «L'adoption internationale», RCADI, 1983-II, pp. 295-412.

${ }^{40}$ Art. 66.IV Ley belga DIPr. 16 julio 2004: «Les juridictions belges sont compétentes pour prononcer la révision d'une adoption aux conditions visées à l'alinéa ler, si l'adoption a été établie en Belgique ou si une décision judiciaire établissant l'adoption a été reconnue ou déclarée exécutoire en Belgique». 


\section{COMPETENCIA INTERNACIONAL DE LOS CÓNSULES ESPA- ÑOLES EN MATERIA DE ADOPCIÓN INTERNACIONAL}

40. La adopción consular es una figura ligada a tiempos pasados (J. A. París Alonso, M. Paz AgÜERAS ${ }^{41}$ ). En efecto, esta figura se creó para que los colonos occidentales desplazados a América y otros países muy alejados de la metrópoli pudieran constituir adopciones en Estados que no disponían de autoridades al efecto. La LAI no ha eliminado la adopción consular. Aunque se ha dicho, no sin acierto, que la adopción consular genera una «escasa práctica» (C. Esplugues Mota / J. L. Iglesias Buhigues, N. BouzA VidAL, J. M. EsPinAR Vicente, P. RodRíGueZ MATEOS ${ }^{42}$ ), esta adopción consular puede resultar útil en ciertas ocasiones en las que quizás puede operar en interés del menor adoptando (A. Durán Ayago, J. M. PAZ AgÜERAS) y sintoniza con la labor general de los Cónsules en materia de estado civil (P. Rodríguez Mateos ${ }^{43}$ ). Pues bien, en todo caso, el Cónsul debe disponer de «competencia internacional» para constituir la adopción. Al respecto cabe subrayar estos datos (art. $17 \mathrm{LAI}$ ).

41. El art. 5.f) del Convenio de Viena de 24 abril 1963 sobre relaciones consulares indica que el «Estado receptor» puede negar a los cónsules extranjeros la posibilidad de constituir adopciones consulares en su terri-

41 J. A. París Alonso, Manual de Registro Civil para los Registros Civiles Consulares, 3. ${ }^{a}$ ed., Madrid, 1996; J. M. PAZ AGÜERAS, «La adopción consular. El problema de la propuesta previa», BIMJ, núm.1552, 1990, pp. 519-539; ID., La adopción consular. Ministerio de Asuntos Exteriores, Madrid, 1990.

${ }^{42}$ C. Esplugues Mota / J. L. Iglesias Buhigues, Derecho internacional privado, Ed. Tirant Lo Blanch, València, 2008, p. 357; P. RodríGueZ Mateos, «Art. 9.5 Cc.», Comen-

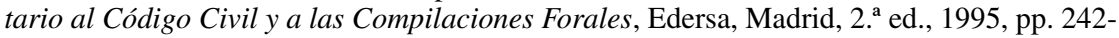
259; J. M. ESPINAR ViCENTE, «La modificación del art. 9.5 Cc. en el Proyecto de reforma sobre adopción», RJ La Ley, 1986, pp. 996-1002; ID., «La adopción de menores constituida en el extranjero y el reconocimiento de la patria potestad en España (algunas reflexiones en torno a la heterodoxa doctrina de la DGRN)», $A C$, 1997, pp. 757-771; J. M. EsPINAR VICENTE, El matrimonio y las familias en el sistema español de Derecho internacional privado, Civitas, Madrid, 1996, pp. 372-374; N. BouZA VIDAL, «La nueva Ley 21/1987 de 11 de noviembre y su proyección en Derecho internacional privado», RGLJ, 1987, pp. 897-931.

43 A. DuRÁn AYAGO, «La filiación adoptiva en el ámbito internacional», La Ley, núm. 5272, 21 marzo 2001, pp. 3-14; ID., «El papel de las entidades colaboradoras de adopción internacional», en A.-L. CALVo CARAVACA Y OTROS, Mundialización y familia, Madrid, 2001, pp. 325-346; J. M. PAZ AGÜERAS, «La adopción consular. El problema de la propuesta previa», BIMJ, núm. 1552, 1990, pp. 519-539; ID., La adopción consular. Ministerio de Asuntos Exteriores, Madrid, 1990; M. A. CAlzadilla Medina, La adopción internacional en el Derecho español, Madrid, Dyinson, 2004, pp. 296-305; P. RodRíGUEZ MATEOS, La adopción internacional, Oviedo, 1988, p. 137. 
torio ${ }^{44}$. Es el caso de Suiza (RDGRN 19 septiembre 1974). En estos supuestos, el Cónsul español no puede constituir la adopción y, si lo hace, la adopción será nula de pleno derecho tanto en el Estado en cuyo territorio ha actuado (= que tiene prohibido expresamente a los Cónsules extranjeros que constituyan adopciones en su territorio), como para España (= por falta de competencia internacional del Cónsul). El Estado receptor del Cónsul español puede negar a los Cónsules españoles la facultad de constituir adopciones en su territorio bien en su legislación interna, o bien mediante un «acto de voluntad política» (= decisión ad hoc dirigida a España o al Cónsul español en el extranjero). Ambos supuestos están previstos expresamente por el art. 17 LAI (= cuyo texto es meridiano al respecto cuando indica que: «[s]iempre que el Estado receptor no se oponga a ello, ni lo prohíba su legislación...). El Estado extranjero receptor (= Host State) puede negar también que se constituyan adopciones en su territorio por Cónsules de otros países aunque sólo en el caso de que el adoptando ostente la nacionalidad del Host State (= Estado extranjero en cuyo territorio ejerce sus funciones el Cónsul español).

42. En el caso de que el «Estado receptor» permita a los Cónsules españoles acreditados en dicho Estado la constitución de adopciones internacionales, el Cónsul español sólo dispone de competencia para constituir adopciones si concurren, además, dos circunstancias de modo cumulativo: $1 .^{\circ}$ ) El adoptante debe ser «español». $2 .^{\circ}$ ) El adoptando debe tener su residencia habitual en la demarcación consular correspondiente. Como antes se ha avanzado, en el caso de que el adoptando sea nacional del Estado extranjero en el que se halla acreditado el Cónsul español, dicho Estado puede privar a dicho Cónsul de la posibilidad de constituir una adopción internacional en su territorio (J. M. EsPinAR Vicente, P. RODRÍGUEZ MATEOS ${ }^{45}$ ).

\footnotetext{
${ }^{44}$ Art. 5 Convenio de Viena de Relaciones Consulares, hecho en Viena el 24 de abril de 1963 (BOE núm. 56 de 6 de marzo de 1970): «Funciones consulares. Las funciones consulares consistirán en: (....) f) actuar en calidad de Notario, en la de funcionario del registro civil y en funciones similares y ejercitar otras de carácter administrativo, siempre que no se opongan las leyes y reglamentos del Estado receptor; (...)». Vid. M. GuZMÁN PECES, La adopción internacional. Guía para adoptantes, mediadores y juristas, Ed. La Ley, Madrid, 2007, pp. 233-236.

${ }^{45}$ J. M. EsPinAR ViCENTE, «La modificación del art. 9.5 Cc. en el Proyecto de reforma sobre adopción», RJ La Ley, 1986, pp. 996-1002; ID., «La adopción de menores constituida en el extranjero y el reconocimiento de la patria potestad en España (algunas reflexiones en torno a la heterodoxa doctrina de la DGRN)», AC, 1997, pp. 757-771; P. RoDRíGUEZ MATEOS, «Adopción internacional», EJB, 1995, pp. 353-354; ID., «Art. 9.5 Cc.», Comentario

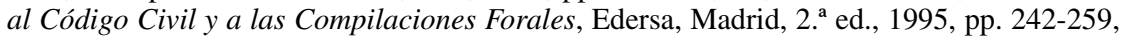
esp. p. 250.
} 
43. El art. 17 in fine LAI deja muy claro que la nacionalidad española del adoptante y la residencia habitual del adoptando se determinarán en el momento de inicio del expediente administrativo de adopción. Con ello, el precepto sigue los criterios sostenidos con anterioridad por la doctrina (J. D. GONZÁLEZ CAMPOS, C. ESPLUGUES MOTA ${ }^{46}$ ).

44. El art. 17 LAI es técnicamente superior al viejo texto, ya derogado, que se contenía en el art. 9.5 Cc. y que regulaba la adopción consular por varias razones: $\left.1 .^{\circ}\right)$ En efecto, este precepto se refería al concepto jurídico de «domicilio del adoptando». Ello hacía surgir dudas sobre la legislación que debía aplicarse para precisar dicho concepto de «domicilio». El legislador de la LAI concede la razón a los autores que sostenían que el «domicilio» debía precisarse con arreglo al Derecho sustantivo español y, en concreto, con arreglo al art. 40 Cc. (= precepto que identifica «domicilio» con «residencia habitual») (A.-L. Calvo Caravaca / J. Carrascosa GonzÁlez ${ }^{47}$ ). 2. ${ }^{\circ}$ ) El art. 17 LAI emplea directamente el foro de competencia consular basado en la «residencia habitual» del adoptando, y elimina toda referencia al «domicilio». De ese modo, las dudas anteriores quedan zanjadas de raíz. La residencia habitual es un «criterio de hecho» y no un «concepto jurídico». En consecuencia, el Cónsul español debe acreditar que el adoptando dispone de su «centro social de vida» en el territorio de su demarcación consultar, sin consultar el Derecho de ningún Estado en particular. Ello simplifica, sin duda, la aplicación de la norma.

\section{CONSIDERACIONES FINALES}

45. La regulación de la competencia judicial internacional en la Ley 54/2007 de 28 de diciembre 2007 de adopción internacional resulta particularmente interesante porque el legislador acoge posiciones vanguardistas, audaces, y, lo más importante, soluciones verdaderamente «creativas». El legislador que ha redactado la LAI ha dejado atrás posiciones dogmáticas, algebraicas, simplistas y ancladas en ideas fijas. Los arts. 14-15 LAI son preceptos auténticamente desafiantes. Admiten en su seno principios que parecen antagónicos y los combinan en una justa dosis. Consciente el legislador

46 J. D. González CAmpos, «Filiación y alimentos», en J. D. González Campos y otros,

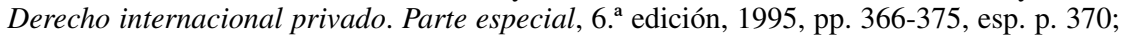
C. EsPlugues Mota, «El 'nuevo' régimen jurídico de la adopción internacional en España», RDIPP, 1997, pp. 33-74.

47 A.-L. Calvo Caravaca / J. Carrascosa González, Derecho internacional privado, vol. I, 8. ${ }^{\text {a }}$ ed., Granada, Ed. Comares, 2007, pp. 181-191. 
de la conveniencia de abrir la jurisdicción española de modo generoso para facilitar la constitución de adopciones internacionales, atempera dicha apertura mediante «cláusulas de desvinculación» que deben ser desarrolladas por los tribunales. La LAI cree en los jueces y en el desarrollo judicial de las soluciones legales. En los arts. 14-15 LAI se percibe que el legislador ha aceptado la idea de que el DIPr. español se construye mediante la adecuada combinación entre reglas «legales» (= previstas para los casos tipo, casos generales) y reglas de «creación judicial» (= para los casos más complicados, Hard Cases). El legislador ha sido también atrevido y valiente al regular la competencia judicial internacional en relación con instituciones legales no existentes en Derecho español, como la «revisión» de la adopción y las «adopciones simples». El legislador de 2007 ha sido «creativo». Ha practicado el «acto bisociativo», el «pensamiento lateral» y ha mostrado una tendencia muy interesante a «saltar de nivel». Ha planteado nuevos problemas y ha proporcionado nuevas soluciones sin temor. Todo este arsenal de técnicas intelectuales ha sido empleado por el legislador en la construcción de buena parte de las soluciones legales en relación con la competencia judicial internacional en materia de adopción. El legislador español de 2007 ha sabido cómo relacionar entre sí ideas lejanas to bring things together. Ha sido capaz de asumir y combinar ideas que, contempladas de modo aislado, a otros sujetos les parecen contradictorias o imposibles. Ha sido un legislador muy receptivo a las ideas de otros legisladores, de los tribunales y de la doctrina. El legislador de 2007 ha sabido «pensar en direcciones opuestas», aceptar la contradicción. Y lo más importante, el legislador de 2007 responsable de la LAI ha sabido asumir el reto de «dejar abiertas las conclusiones». Para el legislador, la Ley 54/2007 es una opera aperta (= el texto escrito de la LAI «crece» con la aportación de quien lee dicho texto, de quien lo aplica y de quien lo explica). En el fondo, el legislador concibe la LAI como una «creación coral». El legislador responsable de la LAI no ha temido la ambivalencia, ni la contradicción ni la complejidad, porque todo ello conforma un «caldo intelectual» que opera como un auténtico estímulo para una más justa aplicación del sistema jurídico. El legislador español responsable de la LAI 2007 ha sido un legislador creativo. 